Article

\title{
"Home Is Where I Spend My Money": Testing the Remittance Decay Hypothesis with Ethnographic Data from an Austrian-Turkish Community
}

\author{
Silke Meyer \\ Department of History and European Ethnology, University of Innsbruck, 6020 Innsbruck, Austria; \\ E-Mail: silke.meyer@uibk.ac.at
}

Submitted: 30 August 2019 | Accepted: 20 January 2020 | Published: 25 March 2020

\begin{abstract}
Remittances - money sent back by migrants to their place of origin-are considered to be both economic and social practices mapping out a transnational space of migration. By sending and receiving money, objects, ideas, and social norms, migrants and non-migrants strengthen their social ties and express their multiple belongings. Remittances can thus be read as a practice of multi-local participation and inclusion. When remittance develops a negative trend, the remittance decay hypothesis thus concludes a shift in belonging: The longer migrants stay in their host country and build a life there, the less they remit. In this article, the remittance decay hypothesis is tested with ethnographic data from interviews and participant observation in the migration nexus between Uşak, Turkey, and Fulpmes, Austria. Remittance to Turkey has declined markedly in the last two decades from a record high of 574 USD million in September 1998 to a record low of 11 USD million in August 2019. Ethnographic data with members of three generations of Turkish-Austrians in Fulpmes can help to explain this process from a diachronic perspective: for changing remittance practices and a transformation in remittance scripts, e.g., as investment, compensation, help, gift or charity donation, demonstrate that there is more to the story than a fading sense of belonging.
\end{abstract}

\section{Keywords}

Austrian-Turkish labor migration; remittance decay; remittances; social script; transnationalism

\section{Issue}

This article is part of the issue "Boundary Spanning and Reconstitution: Migration, Community and Belonging" edited by Anya Ahmed (University of Salford, UK).

(C) 2020 by the author; licensee Cogitatio (Lisbon, Portugal). This article is licensed under a Creative Commons Attribution 4.0 International License (CC BY).

\section{Introduction}

Remittances-money sent back by migrants to their place of origin-are considered to be economic and social practices indicating transnational networks between senders and recipients. By sending and receiving money, objects, ideas, and social norms, migrants and non-migrants strengthen their social ties and express their multiple belongings in a transnational social field. The remittance money is earmarked as multi-sited acts of solidarity, expressions of nostalgia, social glue, or powerful tools of controlling a network one has left behind. As such, they reflect individual commitments, priorities, and difficult decisions in transnational biographies (for the transnational perspective see Basch, Glick
Schiller, \& Szanton Blanc, 1994; Faist, 2010; Vertovec, 2009; Waldinger, 2015).

The decision to become mobile is in most cases connected to the hope of financial advancement, access to work, prosperity, and security: a decision not always made individually, but by families and villages. It is not only the mobile who-despite the hardship and personal sacrifices-eventually profit from advancement through migration, but also those who stay behind. The gains of mobility are shared between the place of destination, the place of origin, and beyond, for transnational lives not only bridge host and home countries, but spread out to other family locations and workplaces.

Remittances thus map out a dynamic network with changing stakes, and the changes in amount, rhythm, 
and practices draw attention from remittance agents as well as from remittance researchers. Theories of economic development and of social inclusion are applied to explain why, where, and when the money flows or runs dry. In this article, I aim to contribute to these explanations with a focus on the remittance development in the migration nexus between Austria and Turkey. Remittances to Turkey show a marked decline for the last two decades. According to the Central Bank of the Republic of Turkey, remittance to Turkey showed a steady increase up to a record high of 574 USD million in September of 1998 and then dropped to an all-time low of 11 USD million in August of 2019. In October 2019, they increased slightly to 17 USD million (Trading Economics, n.d.). Interestingly, Turkey has also become a remittance sending country due to the growing number of return migrants and the even bigger number of Syrian refugees sending money to their home country. From an economic point of view, reasons for the changing remittance behavior can be found in the recession in Turkey's economy, inflation, and politics of exchange rate in the late 1990s. With a weak Turkish Lira, the sending of money became less profitable. Negative developments have led to the remittance decay hypothesis, which states that, over time, migrants send less money to their place of origin (Lucas \& Stark, 1985). The longer migrants live abroad and the more they enjoy social participation and inclusion in the place of residence, the less they remit (Carling, 2008; Vargas-Silva, 2006). This change is often interpreted as a shift of belonging: While migrants still feel closely connected to their homeland during the first years abroad, this connection loosens over time and with social advancement (Mahmud, 2017). Generations differ in their perception of remittance obligation and integration (Cingolani \& Vietti, 2019). The transformation of transnational engagement thus indicates varying stages of social inclusion, meaning that migrants follow and "fulfill a normatively prescribed social

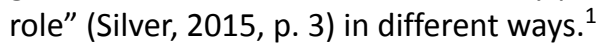

Fresh perspectives on the relation between remittances and social inclusion can be found through an ethnographic approach and with qualitative data from interviews and participant observation. The objective of this article is to complement and explain the remittance decline in a more nuanced way by, first, contextualizing remittance practices in a diachronic perspective, and second by applying the analytical tool of the remittance script (Carling, 2014) and interpreting the social positions associated with remitting. Introducing the perspective of remittance agents, it becomes evident that there is more to the story than a shift of belonging between 'here' and 'there.' Remittance motivation is dynamic and not without ambivalence. The interpretation of social in- clusion needs to be conceptualized accordingly as intersectional with multiple belongings taking geographic origin as well as social, ethnic, and religious membership into account.

The relation between remittances and integration needs to consider both the economic capacity and the desire to remit. Carling and Hoelscher (2013) show that remittances are determined by the resources migrants have and by the strength of ties to their country of origin. Socio-cultural integration plays a marginal role; the sense of belonging to Norway has no effect on remittance sending (Carling \& Hoelscher, 2013, p. 954).

Bivand Erdal and Oeppen (2013) relate the transnational perspective and integration into three patterns. The first one is an antagonistic relationship in which transnational lives and integration hinder each other. Much in line with the remittance decay hypothesis, the motivation for money transfers is seen as a consequence of lacking the feeling of social inclusion in the host country, a change in remitting therefore as a shift in integration. Marini (2014, p. 309) states that transnational involvement can constitute "a kind of 'refuge"' when migrants feel marginalized in their host country. Remitting becomes a way of dealing with social exclusion by expressing closeness to one's home community. Second, transnational lives and integration can be seen in a complementary way in which they happen in parallel without influencing each other. Third, transnational lives and integration can reinforce each other, create synergies, and thereby produce a sum that is bigger than its parts. I have described this outcome as transnational capital (Meyer, 2019), which enables individuals to draw on their (family's) past mobility and to weigh in transnational experiences and knowledge to their benefit. In this sense, remittance agents fulfill their social role with a pay-off in recognition and acceptance in the transnational field.

\section{Theoretical Framework: Remitting as Social Script and the Remittance Decay Hypothesis}

Remittances figures are impressive. Worldwide, the sum of private money transfers is more than three times as high as official development assistance. According to the World Bank, global remittance in 2018 amounted to over 689 billion US dollars, and 714 billion US dollars are predicted for 2019 (World Bank Group, 2019, p. 3). The unofficial sum of informal remittances surpasses this figure considerably. Accordingly, developmental and financial agencies pay close attention to remittances as a means of policymaking. The significance of these transfers for the countries of origin is undisputed: Successfully established remittance transfers enable households and communities to support themselves in the long term and pro-

\footnotetext{
${ }^{1}$ In migration research, the terms of integration and inclusion are not interchangeable. Integration means equal access to economic, social and cultural resources of society for a minority group. In the last decade, the term has been criticized because it does not take structural inequality into account and polarizes between 'us' and 'them.' Non-integration has been judged as individual failure on behalf of migrants. The term 'inclusion' has replaced 'integration' because it focuses on society as a whole and aims to create structures of equality and participation. An inclusive society understands itself as a migrant society in a historical and contemporary perspective: Migration is the norm and not a state that has to be remedied by integration. I use the term inclusion in this article with the exception of those passages referring to other authors using integration in the related texts and passages.
} 
mote social and economic development. International health and education policies are also attuned to the level of private financing, with an often corresponding range of criticisms being directed towards the neoliberal impact of remittances. For, as the sum of private transfers from abroad rises, state investors see less incentive to promote public hospitals, schools, and other educational institutions (Orozco, 2013). Remittances have thus positive as well as negative effects: They enable development, education, health care and independence from state institution and economic volatility, but, at the same time, keep individuals depending on family and relatives and cause the state to withdraw from providing infrastructure for people in need.

From an anthropological point of view, however, remittances are more than just instruments of developmental support. They are the trajectories of social relationships and networks, expressions of solidarity and sentiments of nostalgia as well as measures of support and control. They also are accompanied by conflict and cognitive dissonances over the question of where to spend money, in the place of origin or in the place of residence (Carling, 2008). Remittances should not be understood just as a money transfer and are not limited-despite the 're-'-to a one-directional economy of gifting. Peggy Levitt uses the term social remittances to point out that sending money goes hand in hand with the transfer of objects, values, norms, narratives, practices, identities, and social relationships (Boccagni \& Decimo, 2013; Levitt \& Glick Schiller, 2004; Levitt \& Lamba-Nieves, 2011; Levitt \& Sørensen Nyberg, 2004; Nowicka \& Šerbedžija, 2016). Remittances thus encompass money, foodstuffs, clothing, home furnishings, furniture, carpets, and tools, but also notions of masculine and feminine roles, of family and childhood, of sustainability, climate protection and recycling, health and care, democracy and freedom, and many other issues. The exchange is accompanied by visits to and from the beneficiary countries and by communications like emails, letters, and telephone, Skype, and FaceTime contacts. The practices of transfers especially show a great variety: People carry remittance money while visiting their place of origin and, despite the risk of being caught at the border or airport, deliver it in person to family members, relatives, and administrators of associations. Money is also sent to formal or informal intermediaries who then distribute it to recipients. Money is wired to bank accounts through banks or financial institutions like Western Union. High fees and risk considerations play an important role in the choice of transfer. Sometimes a purpose of use is communicated along with the money transfers. The transfers can be regular or irregular and they vary in the amount of money sent.

Motivations to remit interchange from investment to charity, and the attributions ascribed to the monies sent and received are manifold: For the senders, remittance practices represent nostalgic ties as well as the generosity and a willingness to help. Simultaneously, expectations that migrants will share their ostensibly better life with those they left behind are high and result in social pressure (Lindley, 2010). From the point of view of the beneficiaries, the money is earmarked with attributions of subsistence aid, gratitude, but also interference from outside, even blackmail in cases where the transfers arrive with explicit instructions on how the money is to be spent. Simultaneously, remittances do not just form a bond between the senders and the beneficiaries; they also impact their social environments and contribute to the social and symbolic capital of remittance agents. Money transferred abroad can represent a sense of community but can also be critically viewed as a form of social freeloading in cases where no money is invested into the host country. The possibilities of consumption enabled by money sent from abroad are status symbols. However, they also lead to criticisms of materialism and superficiality. Money transfers enable education, allowing children of migrant families to attend school and university. Nevertheless, these better-educated young people are particularly more likely to then leave their communities to earn money elsewhere. Brain drain and remittances stand in a direct causal relationship to one another, yet are viewed very differently (Özden \& Schiff, 2006). Depending on the country, money transfers may support political activity or even fall under suspicion of financing anything from political resistance through to terrorism (Mascarenhas \& Sandler, 2014). The earmarking of remittance money turns remitting into a social practice (Page \& Mercer, 2012) binding together sender and recipient in a collective process of meaning-making and socialization.

Carling (2014) described these earmarking processes as a social script. Having noticed a certain "remittance fatigue" (Carling, 2014, p. S219) in the economists' and policy circles, he makes a compelling case for ethnographic studies which use "extensive face-to-face interaction with remittance senders and recipients" and thereby "gain an in-depth understanding of issues that escape the standardized optic of surveys" (Carling, 2014, p. S219). As an analytical tool, he introduces the remittance script. Scripts summarize structures of expectations that facilitate social interaction in specific types of situations and allow for recognition and social acceptance in communication and practice. In the remittance context, "scripts make up a repertoire of generalized representations of remittance transactions that are recognized by a social group, but might not be explicitly expressed" (Carling, 2014 , p. S221). They include "the transaction's constituent roles, actions, and statuses, and the relations between these elements" (Carling, 2014, p. S221). By engaging scripts, remittance agents succeed "in making sense of and directing specific and recurring remittance transactions" (Carling, 2014, p. S221). They also claim a social position for themselves which enables them to deal with conflict, multiple demands, and emotional challenges. Scripts like allowance, help, gift, and investment vary in their logic, but they all facilitate social positioning for the subjects involved. 
The script tool becomes particularly helpful in making sense of changes in remitting. The decline in remittance money is theorized by the remittance decay hypothesis: According to this model, migrants send less money to their place of origin, the longer they live in their host country and the more money they earn. Lowering the rate for remittances is also explained by family dynamics. Close family members are likely to join the migrant and relations with more distant family members may weaken over time. The death of parents also often represents a cut in remittance relations (Carling, 2008, pp. 593-595; Holst \& Schrooten, 2006; Lucas \& Stark, 1985; Makina \& Masenge, 2015; Rapoport \& Docquier, 2006). Bettin and Lucchetti (2012) claim that each year migrants live in the country of residence, remittances decrease. Evidently, the dynamics of remittances depend on many factors like the length of the stay abroad, plans to return, recipients of remittances (immediate family, friends, and neighbors, collectives like villages or hometown associations) and motivation to remit (altruistic like charity or self-interested like investment). However, findings for the dynamics and development of remittances are mixed. De Wit, Merritt, and Khan (2015), for example, contradict the decay hypothesis and shows that immigrants in the Netherlands do not send less money home as long as they know people there and have plans to return.

A temporal pattern shows an increase in remitting in the first ten years after migration, a decrease in the following ten years, followed by an increase after twenty years. Makina and Masenge (2015) confirm this inverted U-pattern in their study of South African migrants. Family dynamics can explain this: In the first ten years, the immediate family is still in the place of origin and needs support from the migrant breadwinner. After a family reunion, there are more people to support in the place of residence and less money is available to remit. When immigrants have settled economically and their children are more or less financially independent, remittance is likely to increase again. Motivation to remit (again) could be elderly parents in need. Integration into the society of residence does not play a role in the findings of de Wit et al. (2015). Mahmud (2017) argues differently in his comparison of migrants' remittances in the USA and Japan. Taking into account the impact of the destination state such as immigration policies regarding entry, the period of stay and access to the labor market, as well as social mobility become factors in the decrease of remittances sent. The better immigrants are integrated, the less they send home (Mahmud, 2017).

\section{Methods}

The development of remittances sent to Turkey follows the negative trend of the remittance decay hypothesis. The mixed findings on the dynamics of remitting show that remittance research needs to be highly context-specific. Anthropology relies on an ethnographic approach in order to survey the motives and meaning behind remittance transfers on a micro-level. To this purpose, the research project 'Follow the Money: Remittances as Social Practice' (2016-2020, funded by the Austrian Science Fund) explored the changes in remitting and the relation between money transfers and social belonging in the transnational field of Uşak, Turkey, and Fulpmes, Austria, in an ethnographic study. The focus on remittance agents provides data on the purpose, meanings, and motives for sending money. Our findings are contextualized with an evaluation of remittance literature. The analysis with the focus on Uşak and Fulpmes is a case study in the larger context of Austrian-Turkish labor migration. In accordance with ethnographic analysis, our findings and readings presented here are not representative but significant for our case. Statements from interviews are chosen because they not only account for an individual opinion but also represent a shared opinion within the migration discourse.

In the project, we applied mixed methods of transnational participant observation in both places and furthermore studied the role of transnational objects like houses, interior design, food, and clothes (cf. Bivand Erdal, 2012; Bürkle, 2016; Hahn \& Neumann, 2019; Lopez, 2015; van der Horst, 2010). During our fieldwork from 2015 to 2020, we have also conducted a series of qualitative interviews with 63 male and female migrants from the first, second, and third generation of the labor migration between Turkey and Austria, and with people in Fulpmes and Uşak who were affected by migration. First-generation migrants came to Fulpmes during the 1970s. Their children, the second generation, were generally born in Turkey and followed their parents in the late 1970 s and early 1980s. The third generation was born and raised in Austria in the 1990s. We can thus introduce a historical perspective on changes in remitting from the 1970s to today. The interviews were conducted in Fulpmes and Uşak in German and Turkish, and address the transforming remittance practices and motives, the handling of money in Austria and Turkey, and the feeling of belonging in relation to transnational payments. Due to the heightened political tension in Austrian-Turkish relations since 2016 and the methodological sensitivity on investigating private money transfers, some interviews were not recorded but manually jotted. Often, statements in interviews stood in contradiction to actual practices in the field. Therefore, the participant observation, which was conducted over five years in countless remittance sites in Austria, Turkey, and beyond, adds important aspects. For the analysis, we used the software tool MAXQDA in order to identify relevant themes and their relation to one another.

\section{The Remittance Nexus Uşak and Fulpmes}

The context for our remittance study is the historical and present-day migration nexus between Turkey and Austria. Turkey has shown a negative trend in remittance 
income for almost twenty years now with a drop from 574 USD million in September of 1998 to 11 USD million in August of 2019 (Trading Economics, n.d.). This decay has economic, legislative, administrative, and political as well as social and cultural reasons. From the 1960 s to the 1990s, a favorable exchange rate, interest rate differential, differing income, and expense levels, low risk and financial regulations promoted remitting and savings in Turkish banks. Migrants took advantage of this opportunity and contributed to the large amounts of remittances sent to Turkey. Between 1999 and 2001, the Turkish economy dealt with recessions, and sending money to Turkey had become much less attractive. At the same time, families reunited and the number of dependents on the resident migrant increased. Accordingly, emigrants spent more money on their families in Austria and less money on relatives in Turkey (Koc \& Onan, 2004).

Economic crunches between 1999 and 2001 are considered to be responsible for the remittance drop after 1998 (Karamelikli \& Bayar, 2015). The Turkish economy no longer provided attractive investment opportunities and Turks abroad who sought to invest their savings in businesses, real estate projects and area development looked for other options. Furthermore, the black market, inflation, exchange rate politics, and the military administration in Turkey affected remittance flows (Tuncay Aydas, Kivilcim, \& Bilin, 2005).

Elitok, Bettin, and Straubhaar (2012) summarize that the decision to reside in the host country, the fading attachment to the homeland, and the changes in socioeconomic status in the place of residence through prospering entrepreneurship were all reasons for migrants to remit less money. The authors also state that during and after the economic crisis in Turkey around 2000, migrants tended to remit through unofficial channels, which impacted the official remittance statistics without sending less money. After 2003, statistics showed a further decline, when the Central Bank of Turkey changed their classification of workers' remittances and excluded foreign exchange accounts and money spent during visits to Turkey (Mouhoud, Oudinet, \& Unan, 2006). The drop in interest rates and the rise in tax on remittances lead to further decline. After 2008, the global financial crisis also affected remittances to Turkey and resulted in further downward development. Although Akkoyunlu (2012) shows that remittance from Germany to Turkey picked up again in 2009 and explains this trend with the relatively stable economic conditions in Germany and with the altruistic motive of supporting family and villages rather than investing money for self-interest, the decrease continued overall. Next to the financial development, Elitok (2013) gives two more reasons: the growing return migration to Turkey and the growth of the Turkish economy. Per capita income had almost tripled, from $\$ 3,500$ in 2002 to $\$ 10,524$ in 2011 (Elitok, 2013 , p. 2). Both factors cause an inversion of remittance trends and a growing development of money sent from Turkey to countries like Germany and Austria. Elitok (2013) also comments on the turbulences of the Gezi Park protests and the impact of political instability on the economy. Since then, Turkish politics have changed dramatically. The failed coup d'etat in 2016 causes another economic crunch and a continuous downward trend in the economy with inflation and unemployment both rising to a rate of $10 \%$. The Turkish Lira dropped in value, and the Central Bank had to raise the base rate in order to stabilize the currency. Nevertheless, Recep Tayyip Erdoğan and his government have managed to put a positive spin on political and economic developments. The narrative of the New Turkey as a strong state and market is omnipresent in the national discourse, both in Turkey and in the Austrian diaspora.

My aim is to shed more light on the finding of a negative trend in remitting to Turkey. For this purpose, I take a closer look at the practices as well as scripts and motives of remitting in the migration nexus between the province and city of Uşak in Turkey and the municipality of Fulpmes in Tyrol, Austria. Uşak lies in the west of Turkey, on the geographic and cultural border between the Aegean and central Anatolia. The city has 200,000 inhabitants, of whom many work in agriculture and the textile industry. Following the recruitment agreement between Austria and Turkey signed in 1964, the request by the federal state of Tyrol for male laborers was conveyed to Uşak, with the pioneering migrants arriving in Kufstein, Innsbruck, Hall and, of course, Fulpmes (on labor migration to Tyrol and Austria see Bischof \& Rupnow, 2017; Hetfleisch, 2015; Tiroler Volkskunstmuseum, 2017). The rural market town of Fulpmes lies in the Stubaital, a valley in Tyrol about twenty kilometers away from Innsbruck. Fulpmes has about 4,000 inhabitants and is shaped by tourism both in winter and summer with numerous ski and leisure areas. Historically, Fulpmes was defined by the smallscale iron industry. The ironworking factories hired the first Turkish labor migrants and today employ their sons, nephews, and grandsons. One-fifth of the population in Fulpmes has a familial connection to Turkey, in particular, to the Uşak region. Of course, the nexus is a broader one with people from the Uşak region who also have migrated to Germany, Belgium, France, and the US. The relations between Uşak and Fulpmes are remarkably strong; they maintain business contacts and school partnerships, and official delegations visit each other regularly. Migration is a success story in Fulpmes. From 2002 to 2004, the Turkish community built a mosque that today also houses the Austrian-Turkish cultural association ATIB. Since 2005, Turkish-Austrians have sat in the municipal council with the political association 'Together for Fulpmes.' Turkish-Austrians keep in close contact with their country of origin (Guveli et al., 2016, pp. 46-48), and the Turkish community in Fulpmes is no exception: Our interviewees confirmed that they speak and write almost daily to family and friends in Turkey. 


\subsection{Changing Remittance Practices}

One of the main factors of change in remitting practices can be found on a practical level and with regard to the formal or informal character of the transactions. Formal remittances enter a state through banks and financial institutions, whereas informal remittances are introduced through private channels and remain unrecorded. Sending money through banks is expensive and paying the fees is "a waste," as our interview partners told us, hence the preference for informal channels in the Turkish community in Fulpmes. In the first two decades after their arrival in Austria, i.e., up to the 1990s, senders tended to use official channels more often because travels to Turkey were expensive, troublesome and not without risk. With better roads, traveling infrastructure and eventually cheap flights available, emigrants tend to visit Turkey more often and carry remittance money into the country with them. The private ways encompass money brought by friends, relatives or visiting migrants, and although it is riskier, it has become the established way, especially for our context of Fulpmes and Uşak, because the two places are connected so closely that there is always somebody traveling to Uşak and willing to take money there. This money does not appear in any remittance statistic. The amount of informal remittances to Turkey is virtually unknown and estimates differ immensely from $35 \%$ to $250 \%$ of formal remittances (Social Science Research Council, 2009). Interviewees tell us that it is a common practice nowadays that intermediaries carry smaller sums under 10.000 EUR (sums over 10.000 EUR must be declared to customs). Some draw an agreed-upon sum from ATMs in Turkey during their visits. Only larger amounts of money are transferred through banks or financial institutions (Kosse \& Vermeulen, 2014). It is thus not the amount of money that changed but rather the mode of transfer. While the change in practice from formal to informal channels is not necessarily related to a feeling of belonging, it has a heavy impact on official remittance figures.

A common remittance practice is investments in Turkish businesses and development plans. During the 1990s, Turkish companies like Gürteks Holding, Kaldera Holding, and Kombassan Holding offered special deals to ex-pat investors to spend money on real estate and companies especially in less developed areas. The supposed aim was to strengthen the Turkish economy and to develop rural areas. Turkish migrants in Fulpmes were told that these companies would provide jobs for their relatives and for themselves upon return migration (Içduygu, 2006, p. 6). One interviewee said: "My plan was to work for a couple of years more in Europe and then return to work in this company until I retire, that is why I invested. And I gave them all I had." Some companies even sent out representatives to Tyrol to promote their investment plan and recruit more stakeholders. An important aspect of the interviews is the religious framing intersecting the economic one: by giving savings to the Turkish compa- nies, the investment would not yield interest, as interest is forbidden in the Muslim faith. Rather, they promised shares in profit, often paid in coupons. Turks in Fulpmes saw a chance to invest their savings according to Islamic conventions and, at the same time, support their home region. Some invested all their money and gold into businesses in Uşak, even took out credit in order to pay in money. They were invited to visit the company sites during their summer holidays, shown around and, initially, given their first shares in profit. After the first payments, however, many companies closed down, entry to the site was forbidden, no jobs were provided, and people lost their savings. The government saw no need to interfere, the then president Mesut Yilmaz supposedly stating that when migrants decided to invest their savings in private businesses (and not in state programs), they should live with the consequences. Many Fulpmes Turks still have the coupons from the schemes and showed them to us. They are material leftovers of dreams of returning to Uşak as both an altruistic benefactor and a rich man.

Part and parcel of analyzing changes in remittance practices is looking at alternative spending. For the Turkish community in Fulpmes, a turning point in the history of remitting is the construction of a mosque in the small town. In the first two decades in Fulpmes, Muslims met at an old theatre to pray. In 2000, they bought the land for a mosque which opened in 2004. Mr. Tamer, who has lived in Fulpmes since 1981 and can be considered a driving force behind the plan, told us that the funds were raised mainly by the members and much of the construction was undertaken independently. The municipality of Fulpmes also contributed to the costs. Membership fees could be paid in advance and the names of those who did so were displayed on the wall of the association's common room. When asked about details of the process, Mr. Tamer started laughing and explained that there had at first been a lot of resistance on the part of his Turkish friends and neighbors to invest in a building in Austria. In his view, the funding of the mosque is the key to understanding Turkish migration because it represents a shift in remittance practices. The majority had at first been unwilling because, after all, they had always sent their money "back down," meaning to Turkey: "Until the 1990s, we did not invest a single cent in Austria. But the real issue is, home is where I spend my money," he says, "and look at this place now: a mosque in Fulpmes; that is quite something."

For years, spending money "at home" had meant supporting family and villages in Uşak. The decision to build a place of Muslim worship and a center for the Turkish community represents an act of commitment as well as an emotional investment in their place of residence, Fulpmes. In the process of building the mosque, it can be interpreted as an antagonistic relationship between a 'there' and a 'here' with financial support being withdrawn from 'there' and spent 'here.' Today, the mosque is an economic and symbolic statement of social inclusion in Austrian society. 


\subsection{Changing Remittance Scripts}

Over time, not only remittance practices but also remittance motives and scripts have changed. Our interview partners sum up their history of remitting: In many families, the first generation had sent all their money down to Uşak in forms of allowances for wives and children. After the first years, the wives followed their husbands to Austria and the couples remitted their double income (if existing) to the grandparents and siblings in the form of compensations so that they could look after the children. When the children followed, support money folded considerably and families started to invest in houses, building plots, and businesses in Turkey. Remittance thus changed from compensation/allowance to investment. According to Carling (2014), compensation represents a balanced-exchange relationship. The money comes regularly, has a clear purpose and the recipient is conveyed an explicit assignment (Carling, 2014, p. S232). Investments are mainly singular transfers and strengthen the sender's position through expected economic and symbolic profit. The character of reciprocity, which was prevailing in the compensation script, is less prominent in the investment script. Investment indicates a future belonging, for example in return migration, rather than a present one. With their orientation towards the future, investments express a multi-dimensional sense of belonging. Investing in businesses and houses is also a form of symbolic participation while being physically absent. This may result in conflict as an inherent structure of remittance scripts. Transnational networks are not merely characterized by their connectivity (Waldinger, 2015) but need to be examined in their brisance, too. In Fulpmes, the Tamer family lived in cramped conditions until the mid-1990stwo rooms with a shared bathroom, the kitchen having been fitted with a shower later on. At the same time, the family invested in a second house in Uşak and had the first house in a village near Uşak renovated, fitted with heating, and expanded. The transnational transactions comprise various social roles: the loyal son, the cautious father, the grateful migrant, the good citizen, and the clever entrepreneur.

Perhaps as a solution to family conflict, another remittance script has become prominent in Fulpmes, which is the earmarking of remittance money as a charity donation. Bivand Erdal and Borchgrevink (2016; see also Borchgrevink \& Bivand Erdal, 2017) intersect the influence of migrant development engagement and religion and show that remittances are framed differently in the context of transnational Islamic charity. Fulpmes Turks send charity payments to Turkey, usually according to the Islamic calendar, sometimes spontaneously to individuals in need. These transfers are not regarded as remittance per se but as a religious obligation, for example as zekat or fidyah. Zekat is a prescribed form of almsgiving and comprises $2.5 \%$ of individual annual assets; fidyah is used to compensate for fast-breaking for sick or old people during Ramadan. Zekat money is distributed ac- cording to financial needs, often to family members or neighbors. Some people send zekat to a local welfare office where they have lists of people in need. Again, the money is carried to Turkey by traveling family members and not sent via financial institutions.

Interviewees talk about zekat and fidyah in great detail and empathy. In fact, we realized that sometimes, it was much easier for some of our interview partners to talk about these monies than about remittance money. Analyzing interviews not only in terms of content but also in terms of conversational convention and social interaction, it is evident that the question about religious monies was answered with greater ease than inquiries after money transfers to brothers, sisters, or cousins. The uncomfortable silences can be explained by a shift in the remittance script. The 'help' script, though including a "moral virtue of both senders and recipients," is "deeply hierarchical and potentially humiliating" and creates "a structural relationship of dependence" (Carling, 2014 , p. S240). For senders today, it does not seem fitting to reinforce this structural inequality. Here, the script of charity donation offers a way out of the dilemma. 'Donations' are characterized by a divine actor as part of the remittance motivation, and religious motivation and humanism overlap (Bivand Erdal \& Borchgrevink, 2017, p. 141). The welfare officer acts as a broker and decides who needs the money the most. In the donation script, the sender-recipient duality is opened up which causes a shift in power and dependency. By remitting donations, senders contribute to a transnational Islamic charity, and their gain is a social as well as a spiritual one.

Among our interview partners, this change of script is most noticeable in the third generation, which was born and raised in Austria. Members of this generation have hardly any experience with remitting and cannot imagine sending money to cousins, uncles, and aunts. They do, however, send zekat to Turkey through informal ways. Zekat money, in their view, is a comfortable way of sending support, because it does not imply dependency, social hierarchy, and interference from outside. Andersson (2010) finds that a change in financial engagements outside the geographic diasporic homeland is characteristic for the second or third generation of migrants, whom she calls the "first-generation Muslim European." Young adults from Fulpmes state that they feel less obligated to support individuals in their families in Turkey. At the same time, they engage themselves for charitable causes outside their own family and beyond the geography of their homeland. Combined with Bivand Erdal and Oeppen's (2013) model, the remittance script of donation to Islamic charity creates synergies and offers a sense of belonging beyond the binary code of origin and residence, home and host. Transnational Islamic faith replaces nationality and ethnicity as a framework of identification.

To frame financial support in religious terms also helps to negotiate the current climate of nationalism in Turkey and in Austrian-Turkish communities. A popular 
narrative related to us in the interviews was the prosperity and wealth of the Turkish nation under the current leadership of the AKP and Erdoğan's government. Especially during our fieldwork in Uşak, questions about remittance were answered negatively; that the transfers are no longer needed, that Turkey offers the same consumer wealth as Austria and that they would not even bring technical equipment and material anymore. "We have everything we need and we no longer depend upon Europe to bring us modern comfort and prosperity," said a respondent, and this statement is the bottom line in many interviews, emphasizing financial independence and, at the same time, responding to longstanding experiences of marginalization, social exclusion, and discrimination. However, donations to Uşak as an act of transnational Islamic charity are still given frequently and talked about. The migration discourse in Austria since the failed coup d'etat in 2016 in Turkey became considerably rough, increasing the pressure on TurkishAustrians to openly display their loyalty to their place of residence. Religion plays a big role in the identity politics of many Turkish-Austrians. This imposed pressure causes backward motions, and by underlying the current strength and independence of Turkey, social integration and assimilation demanded in Fulpmes can switch towards Uşak. However, findings of the participant observation show that these statements are fragile. While one of the first-generation migrants showed us his brand new house in the village he was born in, he underlined that not a single thing was taken there from Europe, as "one can now find everything in Uşak, even with better quality." But, during the tour through the house, we spotted many items, like kitchen equipment and food, which had been brought from Europe.

\section{Conclusion}

Ethnographic studies show that when it comes to remittances, "economics is not the whole story" (Levitt \& Lamba-Nieves, 2011 , p. 2). In this article, I have tested the remittance decay hypothesis with ethnographic data on remittance practices, motives, and social scripts. For the development of remittances to Turkey, the decay hypothesis can be confirmed with regard to temporal patterns in increase and decrease. Migrants remit less when they are joined by their immediate family in the country of residence. However, it is important to consider the diachronic change in remittance practices. An increase in informal practices due to political and administrative reasons can lead to a decline in formal remittances, and thus, overall, towards the picture of a negative trend. This negative development, however, has no relation with a sense of belonging and social inclusion.

More information about social inclusion can be gained from looking at remittance scripts and the earmarking of monies therein. Especially in the trend towards religious donations, we can find the synergetic effects of integration described by Bivand Erdal and
Oeppen (2013). Remitting as part of a transnational Islamic charity provides a kind of social inclusion that overcomes the binary code of 'here' and 'there' and offers social recognition and acceptance beyond geographical determinants. Transnational and local engagement do not compete with each other but constitute a process of social inclusion where 'home' can be in multiple places at the same time.

\section{Acknowledgments}

I would like to credit the Austrian Science Fund for financing the research project 'Follow the Money: Remittances as Social Practice' (P-28929) and express my gratitude to my colleague Claudius Ströhle for his cooperation in the project. My thanks also go to the anonymous reviewers who commented on an earlier version of this article.

\section{Conflict of Interests}

The author declares no conflict of interest.

\section{References}

Akkoyunlu, S. (2012). Turkish workers' remittance from Germany during the crisis. In I. Sirkeci, J. Cohen, \& D. Ratha (Eds.), Migration and remittances during the global financial crisis and beyond (pp. 273-288). Washington, DC: The World Bank.

Andersson, M. (2010). The social imaginary of firstgeneration Europeans. Social Identities, 16(1), 3-21.

Basch, L., Glick Schiller, N., \& Szanton Blanc, C. (1994). Nations unbound: Transnational projects, postcolonial predicaments, and deterritorialized nation-states. London: Routledge.

Bettin, G., \& Lucchetti, R. (2012). Intertemporal remittance behaviour by immigrants in Germany (SOEP Papers 505). Berlin: German Institute for Economic Research (DIW).

Bischof, G., \& Rupnow, D. (2017). (Eds.). Migration in Austria. Innsbruck: University Press.

Bivand Erdal, M. (2012). 'A place to stay in Pakistan': Why migrants build houses in their country of origin. Population, Space and Place, 18(5), 629-641.

Bivand Erdal, M., \& Oeppen, C. (2013). Migrant balancing acts: Understanding the interactions between integration and transnationalism. Journal of Ethnic and Migration Studies, 39(6), 867-884.

Bivand Erdal, M., \& Borchgrevink, K. (2017). Transnational Islamic charity as everyday rituals. Global Networks, 17(1), 130-146.

Boccagni, P., \& Decimo, F. (2013). Mapping social remittances. Migration Letters, 10(1), 1-10.

Borchgrevink, K. \& Bivand Erdal, M. (2016). The circulation of transnational Islamic charity. In M. Nowicka \& V. Šerbedžija (Eds.), Migration and social remittances in a global Europe (pp. 259-280). Basingstoke: Palgrave Macmillan. 
Bürkle, S. (2016). Migration von Räumen. Architektur und Identität im Kontext türkischer Remigration [Migrating spaces. Architecture and identity in the context of Turkish remigration]. Berlin: Vice Versa.

Carling, J. (2008). The determinants of migrant remittances. Oxford Review of Economic Policy, 24(3), 581-598.

Carling, J. (2014). Scripting remittances: Making sense of money transfers in transnational relationships. International Migration Review, 48(1), S218-S262.

Carling, J., \& Hoelscher, K. (2013). The capacity and desire to remit: Comparing local and transnational influences. Journal of Ethnic and Migration Studies, 39(6), 939-958.

Cingolani, P., \& Vietti, F. (2019). "My parents fell behind." Social remittances, integration and generational change among Moldovan immigrants. Journal of International Migration and Integration. Advance online publication. https://doi.org/10.1007/s12134019-00701-z

de Wit, A., Merritt, D., \& Khan, S. (2015). Identification and remittances: Does integration hinder immigrants giving to the country of origin? Paper presented at the 7th International Research Conference of the European Research Network on Philanthropy, Paris. Retrieved from http://ernop.eu/wp-content/uploads/ 2015/06/Arjen-de-Wit-Remittances.pdf

Elitok, S. P. (2013). Remittance flows between Germany and Turkey: A reverse trend? (IPC-Mercator Policy Brief). Istanbul: Istanbul Policy Center, Sabancı University. Retrieved from https://ipc.sabanciuniv.edu/ wp-content/uploads/2013/08/Remittance-FlowsBetween-Germany-and-Turkey.pdf

Elitok, S. P., Bettin, G., \& Straubhaar, T. (2012). Causes and consequences of the downturn in financial remittances to Turkey: A descriptive approach. In S. P. Elitok \& T. Straubhaar (Eds.), Turkey, migration and the EU: Potentials, challenges and opportunities (pp. 133-166). Hamburg: University Press.

Faist, T. (2010). The volume and dynamics of international migration and transnational social space. Oxford: Oxford University Press.

Guveli, A., Ganzeboom, H., Platt, L., Nauck, B., BaykaraKrumme, H., Eroglu, S., . . . Eroglu-Hawskworth, S. (2016). Intergenerational consequences of migration: Socio-economic, family and cultural patterns of stability and change in Turkey and Europe. London: Palgrave Macmillan.

Hahn, H.-P., \& Neumann, F. (2019). Das neue Zuhause. Haushalt und Alltag nach der Migration [The new home. Household and everyday life after migration]. Frankfurt: Campus.

Hetfleisch, G. (2015). Geschichte der Arbeitsmigration Tirols 1945-2013 [History of labor migration in Tyrol 1945-2013]. In R. Garstenauer \& A. Unterwurzacher (Eds.), Aufbrechen, Arbeiten, Ankommen. Mobilität und Migration im ländlichen Raum seit 1945 [Leaving, working, arriving. Mobility and migration in rural areas since 1945] (pp. 95-125). Innsbruck: Studienverlag.

Holst, E., \& Schrooten, M. (2006). Migration and money: What determines remittances? Evidence from Germany. Berlin: German Institute for Economic Research (DIW). Retrieved from https://www.diw.de/ documents/publikationen/73/diw_01.c.44138.de/ dp566.pdf

Içduygu, A. (2006). International migrants remittances in Turkey. Euro-Mediterranean consortium for applied research on international migration (CARIM-AS 2006/07). Fiesole: European University Institute. Retrieved from https://cadmus.eui.eu/bitstream/ handle/1814/11687/CARIM_ASN_2006_07.pdf? sequence $=1$ \&isAllowed $=y$

Karamelikli, H., \& Bayar, Y. (2015). Remittances and economic growth in Turkey. Ecoforum, 4(2/7), 33-40.

Koc, I., \& Onan, I. (2004). International migrants' remittances and welfare status of the lest-behind families in Turkey. International Migration Review, 38(1), 78-112.

Kosse, A., \& Vermeulen, R. (2014). Migrants' chose of remittance channel: Do general payments habits play a role? (Working Paper No. 1683). Frankfurt: European Central Bank. Retrieved from https://www.ecb. europa.eu/pub/pdf/scpwps/ecbwp1683.pdf

Levitt, P., \& Glick Schiller, N. (2004). Conceptualizing simultaneity: A transnational social field perspective on society. International Migration Review, 38(3), 1002-1039.

Levitt, P., \& Lamba-Nieves, D. (2011). Social remittances revisited. Journal of Ethnic and Migration Studies, 37(1), 1-22.

Levitt, P., \& Sørensen Nyberg, N. (2004). The transnational turn in migration studies. Geneva: Global Commission on International Migration.

Lindley, A. (2010). The early morning phone call. Somali refugees' remittances. Oxford: Berghahn.

Lopez, S. L. (2015). The remittance landscape. Spaces of migration in rural Mexico and urban USA. Chicago, IL: Chicago University Press.

Lucas, R. E. B., \& Stark, O. (1985). Motivations to remit: Evidence from Botswana. Journal of Political Economy, 93(5), 901-917.

Mahmud, H. (2017). Social determinants of remitting practices among Bangladeshi migrants in Japan. Sociological Perspectives, 60(1), 95-112.

Makina, D., \& Masenge, A. (2015). The time pattern of remittances and the decay hypothesis: Evidence from migrants in South Africa. Migration Letters, 12(1), 79-90.

Marini, F. (2014). Transnationalism and integration: What kind of relationship? Empirical evidence from the analysis of co-development dynamics. Migration and Development, 3(2), 306-320.

Mascarenhas, R., \& Sandler, T. (2014). Remittances and terrorism: A global analysis. Defence and Peace Economics, 25(4), 331-347. 
Meyer, S. (2019). Remittances und transnationales Kapital [Remittances and transnational capital]. In K. Braun, C.-M. Dieterich, \& J. Moser (Eds.), Wirtschaften. Kulturwissenschaftliche Perspektiven [Economic practices. Anthropological perspectives] (pp. 64-80). Marburg: Makufee.

Mouhoud, E. M., Oudinet, J., \& Unan, E. (2006). Migration and remittances in the Mediterranean Basin: The case of Turkey (Working Paper No. 2006-10). Paris: University of Paris.

Nowicka, M., \& Šerbedžija, V. (Eds.). Migration and social remittances in a global Europe. Basingstoke: Palgrave Macmillan.

Orozco, M. (2013). Migrant remittances and development in the global economy. Boulder, CO: Lynne Rienner Publishing.

Özden, Ç., \& Schiff, M. (2006). International migration, remittances, and the brain drain. Trade and development. Washington, DC: World Bank and Palgrave Macmillan.

Page, B., \& Mercer, C. (2012). Why do people do stuff? Reconceptualizing remittance behaviour in diasporadevelopment research and policy. Progress in Development Studies, 12(1), 1-18.

Rapoport, H., \& Docquier, F. (2006). The economics of migrants' remittances. In S.-C. Kolm \& J. M. Ythier (Eds.), Handbook of the economics of giving, altruism and reciprocity (Vol. 2, pp. 1135-1198). Amsterdam: Elsevier.

Silver, H. (2015). The contexts of social inclusion (UNDESA Working Paper No. 144). New York, NY: DESA. Retrieved from https://www.un.org/esa/desa/ papers/2015/wp144_2015.pdf

Social Science Research Council. (2009). Topic 4: Formal vs. informal remittances. Brooklyn, NY: Social Science Research Council.

Tiroler Volkskunstmuseum. (Ed.). (2017). Hier Zuhause. Migrationsgeschichten aus Tirol [At home here. Migration stories from Tyrol]. Innsbruck: Tiroler Landesmuseum.

Trading Economics. (n. d.). Turkey remittances. Trading Economics. Retrieved from https://trading economics.com/turkey/remittances

Tuncay Aydas, O., Kivilcim, M., \& Bilin, N. (2005). Determinants of workers' remittances: The case of Turkey. Emerging Markets, Finance \& Trade, 41(3), 53-69.

van der Horst, H. (2010). Dwellings in transnational lives: A biographical perspective on 'Turkish-Dutch' houses in Turkey. Journal of Ethnic and Migration Studies, 36(7), 1175-1192.

Vargas-Silva, C. (2006). The determinants of international remittances: Evidence from the legalized population. Academy of Economics and Finance Papers and Proceedings, 30, 333-335.

Vertovec, S. (2009). Transnationalism. London: Routledge.

Waldinger, R. (2015). The cross-border connection: Immigrants, emigrants, and their homelands. Cambridge, MA: Harvard University Press.

World Bank Group. (2019). Migration and remittances: Recent developments and outlook-Brief 31. Washington, DC: World Bank. Retrieved from https:// www.knomad.org/publication/migration-anddevelopment-brief-31

\section{About the Author}

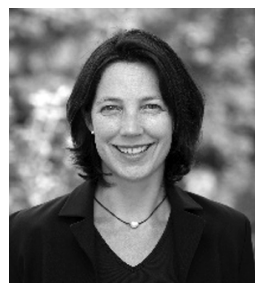

Silke Meyer is Professor of European Ethnology at the University of Innsbruck. Her research interests are economic anthropology, especially remittances and debts economies, as well as narrative analysis. Her current research project studies remittances as social practices in transnational society. She is the speaker of the University of Innsbruck's doctoral program "Dynamics of Inequality and Difference in the Age of Globalization" where she supervises doctoral research on the production of inequality in the context of migration. 